\title{
Cytotoxic, genotoxic and mutagenic potential of UHT whole milk
}

\author{
Brenda de Lima CARVALHO ${ }^{1}$, Ila Monize Sousa SALES ${ }^{1}$, Ana Paula PERON ${ }^{1,2 *}$
}

\begin{abstract}
This study evaluated the action at the cellular level of long life whole milk, full type of six renowned companies operating in the Brazilian market, as well as in other South American countries. The evaluation was performed using root meristem cells of Allium cepa L., at exposure times 24 and 48 hours, directly in milk products marketed. The results indicated that all the milk samples reduced root meristem cell proliferation, proving, in this study, a significant cytotoxic effect. Still, exposure to milk resulted in a significant frequency of mitotic spindle changes in meristem cells, characterizing these foods as genotoxic and mutagenic under the study conditions. It can be concluded that the long life milk samples caused significant genetic instability to cells of the examined tissue. The results obtained for cytotoxic, mutagenic and genotoxic action of these long life milks are of great relevance because, to date, there are no published toxicity studies on such foods and food additives present in the composition.
\end{abstract}

Keywords: ultra-pasteurized milk; cell division; mitotic spindle alterations; meristematic tissue.

Practical Application: Verification of cell toxicity UHT milk in intense proliferation tissue.

\section{Introduction}

Bovine milk is considered a staple food because it contains, naturally and abundantly, biomolecules, such as water, glycides, proteins, unsaturated lipids, vitamins and minerals essential for the proper functioning of the body (Taffarel et al., 2013). However, despite nutritional importance, this food is highly perishable as it also is characterized as an excellent medium for the proliferation of undesirable microorganisms that, upon release of toxins, cause significant changes in taste, smell, color and, hence, nutritional properties (Aguiar et al., 2015).

In this way, to provide a healthy dairy product without contaminants, with extended shelf life and no preservative additives or micro ingredients, flavorings and colorings, food manufacturers have developed effective methods for quality control and preservation, such as the ultra-high temperature (UHT) technique, also known as ultra-pasteurization (Lima et al., 2009; Domareski et al., 2010). Raw milk subjected to this procedure is commercially known as UHT milk or long-life milk, which, based on the content of lipids is classified in whole, semi-skimmed or skimmed milk; and the first type is the most consumed by the population (Domareski et al., 2010; Souza et al., 2014). In Brazil, these dairy products are regulated by the Ministry of Agriculture, Livestock and Supply, through the Technical Regulation of Identity and Quality of long life milk - Ordinance Number 146 of 1995 (Brasil, 1995; Souza et al., 2014). This regulation was developed based on determinations of Codex Alimentarius, a body that regulates general rules for chemical composition, safety and food labeling worldwide (Brasil, 1995; Pflanzer et al., 2010).

However, although it is not attributed to long life milk, flavoring, color and preservative additives - micro ingredients scientifically proven to be toxic at the systemic and cellular levels (Marques et al., 2015; Moura et al., 2016; Sales \& Peron, 2016) - it is added to these food wetting, stabilizer and antioxidant agents which, among other features, have the function to preserve the texture and homogeneity and ensure no oxidation of milk, especially after opened for consumption (Aguiar et al., 2015; Taffarel et al., 2013). Bodies, such as Codex Alimentarius and the National Health Surveillance Agency (ANVISA), point out in their technical regulations the constant need for toxicological studies on the acute effect of food microingredients in general, and especially of foods containing these compounds, since many food additives, such as those with wetting, stabilizing and antioxidant action, have not been evaluated for their cytotoxic, genotoxic, mutagenic and carcinogenic potential (Gomes et al., 2013; Oliveira et al., 2013; Marques et al., 2015; Moura et al., 2016; Nunes et al., 2016). Also, they emphasize that the results of toxicological analyses are the basis for preparation or modification of documents that regulate the basic composition and the daily intake rate or consumption of semi-processed and processed foods (Brasil, 2007; Moura et al., 2016; Sales \& Peron, 2016). Nevertheless, in a broad search in the scientific literature, it was found no studies evaluating toxicity of ultra-pasteurized milk beverages.

Root meristems of Allium cepa L. (onion) are regarded in the scientific community as an effective bioassay for the assessment of acute toxicity at the cellular level of chemical compounds, since they have low chromosome number $(2 \mathrm{n}=16)$, which favors detection of chromosomal or clastogenic changes, alterations in the mitotic spindle or aneugenic activities, and changes in cell proliferation (Türkoğlu, 2007; Neves et al., 2014; Bianchi et al.,

${ }^{1}$ Laboratório de Citogenética e Mutagênese - LaCM, Departamento de Ciências Biológicas, Universidade Federal do Piauí - UFPI, Campus Senador Helvídio Nunes de Barros - CSHNB, Picos, PI, Brazil

${ }^{2}$ Programa de Pós-graduação em Genética e Melhoramento - PPGM, Universidade Federal do Piauí - UFPI, Campus Ministro Petrônio Portella - CMPP, Teresina, PI, Brazil

*Corresponding author: anapaulaperon@ufpi.edu.br 
2015). This test system is internationally accepted by research agencies as an assessment tool with accurate sensitivity for analysis of cytotoxicity, genotoxicity and mutagenicity of the substance of interest, since the results obtained mostly show satisfactory similarity to those obtained via animal testing systems and cell cultures (Herrero et al., 2012; Lacerda et al., 2014; Tabrez et al., 2011; Gomes et al., 2013; Oliveira et al., 2013; Campos-Ventura et al., 2016; Moura et al., 2016; Santana et al., 2016; Bezerra et al., 2016; Sales \& Peron, 2016; Nunes et al., 2016).

Given the addressed context, the present study aimed to evaluate, in root meristem cells of $A$. cepa, the cytotoxic, genotoxic and mutagenic potential of UHT whole milk of six relevant companies in the Brazilian food market, as well as in other countries in South America.

\section{Material and methods}

\subsection{Treatment solutions}

Samples of UHT milk of the six renowned companies operating in the Brazilian market, as well as in other South American contries, hereinafter referred to as A, B, C, D, E and $\mathrm{F}$, respectively - were acquired in the retail market in the city of Picos, state of Piauí, Brazil. We were careful to check the shelf life period of the products and the integrity of packaging. Analyses of toxicity were carried out directly in the milk marketed in packaging.

\subsection{Test of cytotoxicity, genotoxicity and mutagenicity with Allium cepa $L$.}

Onion bulbs were placed in aerated bottles with distilled water at room temperature $\left( \pm 27^{\circ} \mathrm{C}\right)$ to obtain $2.0 \mathrm{~cm}$ long roots. For analysis of each milk sample, it was set up an experimental group with five onion bulbs. Before placing the roots in contact with their respective milk samples (treatments), some roots were collected and fixed to serve as control of the bulb itself. Then, the remaining roots were returned in their respective treatments for 24 hours, procedure called 24-hour exposure time.

After 24 hours, some roots were collected and fixed. Next, the remaining roots of each bulb returned to their treatments where they remained for additional 24 hours, which was called 48-hour exposure time. Subsequently, roots were again collected and fixed. 24- and 48-hour exposure times were chosen to evaluate the effect of long-life milk on more than one cell cycle. Roots were fixed in Carnoy 3: 1 (ethanol: acetic acid) for 24 hours. On average, three roots per bulb were taken in each collection.

Slides, on average, 03 per bulb, were prepared following the protocol proposed by Guerra \& Souza (2002), and analyzed under a light microscope at $40 \times$ magnification. For each onion bulb, we examined 1,000 cells, totaling 5,000 cells for each control, 24- and 48-hour exposure times of each treatment group. In this way, for each milk sample, we analyzed 15,000 cells. These were observed in interphase, prophase, metaphase, anaphase and telophase. For calculation of the mitotic index (MI), we used the following equation: (total number of cells in mitosis $\div$ total number of cells analyzed) $\mathrm{x} 100$. MI values were used as a parameter for the determination of cytotoxicity
Mutagenicity and genotoxicity milk samples was also evaluated by frequency of micronuclei or clastogenic effects and colchicine metaphase, anaphase and telophase bridges, gene amplification, cells with adhesions, nuclear buds and multipolar anaphases, called aneugenic alterations or mitotic spindle changes. For statistical analysis, we used the chi-square test $\left(\chi^{2}\right)$ at a probability level $<0.05$.

\section{Results and discussion}

The results in Table 1 demonstrate that all the samples of UHT milk caused a significant reduction in cell division of root meristems, at 24- and 48-hour exposure times, when compared to their respective controls. Similarly, when confronted with each other, cellular division indices obtained for the 24- and 48-hour exposure times of each sample, we verified a statistically significant inhibition of cell proliferation. Therefore, considering the results in Table 1, it can be inferred that the long life milk evaluated under the conditions of this study, have significant cytotoxicity to the test system used, which was more pronounced and significant with increasing exposure time

The cytotoxic potential of chemical compounds or substances can be determined by increasing or decreasing the mitotic index of tissues exposed to them (Fernandes et al., 2007). According to Caritá \& Marin-Morales (2008), mitotic index lower than that of the negative control indicates the presence of agents whose toxic action affects the growth and development of exposed organisms. Complementing these authors, Gomes et al. (2013), Marques et al. (2015), Sales \& Peron (2016) and Moura et al. (2016) claim that the inhibition of cell proliferation triggered by cytotoxic compounds in tissue with intense cell proliferation and with normal performance or without cellular changes, such as those used in this study for assessment of UHT milk toxicity, is quite harmful to the organism, since it possesses the property of inhibiting or limiting the replenishment of cells, altering the production of proteins and resulting in malfunction of the organ where it is located (Gomes et al., 2013; Marques et al., 2015; Sales \& Peron, 2016; Moura et al., 2016).

The results shown in Table 2 indicate that all the samples of long life milk analyzed, for the 24-hour exposure time, have significantly induced cell changes in the meristematic tissue of roots. However, for all dairy products analyzed, the number of alterations verified for the longer exposure time was statistically lower than the results for the 24-hour exposure time. The reduction in cellular changes observed for longer exposure time corroborates the results of cell proliferation presented in Table 1, once all milk samples dramatically reduced cell division at the 48-hour exposure.

The results shown in Table 2 indicate that all the samples of long life milk analyzed, for the 24-hour exposure time, have significantly induced cell changes in the meristematic tissue of roots. However, for all dairy products analyzed, the number of alterations verified for the longer exposure time was statistically lower than the results for the 24-hour exposure time. The reduction in cellular changes observed for longer exposure time corroborates the results of cell proliferation presented in Table 1, once all milk samples dramatically reduced cell division at the 48-hour exposure. 
Further, UHT milk products analyzed, at the 24-hour exposure time, have induced the formation of colchicine metaphase or C- metaphase in meristem cells, especially at the 24-hour exposure time (Table 2). The significant presence of mitotic spindle alterations shows that the evaluated milk were genotoxic to root cells. In agreement with Aissa et al. (2012), these disorders in tissues exposed to genotoxic agents evidence that such compounds primarily affect the integrity of the nuclear spindle, thus causing the improper alignment of chromosomes at the equatorial plate during mitosis and impeding the normal progress of the cell cycle.

At the shortest exposure time, we observed anaphase bridges, multipolar anaphases and telophase bridges (Table 2). According to Fernandes et al. (2007), bridges found in cells at anaphase and/or telophase occur by the action of chemical agents that significantly affect the mitotic spindle during

Table 1. Number of cells in each phase of cell cycle observed in root meristem of Allium cepa exposed for 24 and 48 hours to samples of whole long life milk of six food companies - referred to as A, B, C, D, E and F. In each treatment, significant values of $\chi^{2}$ are presented.

\begin{tabular}{|c|c|c|c|c|c|c|c|c|}
\hline \multicolumn{9}{|c|}{ MITOTIC INDEX } \\
\hline Company & ET & NIU & $\mathrm{P}$ & $\mathrm{M}$ & A & $\mathrm{T}$ & NDC & MI (\%) \\
\hline \multirow{3}{*}{ A } & $\mathrm{CO}$ & 3943 & 513 & 232 & 150 & 162 & 1057 & $21.4^{\mathrm{a}}$ \\
\hline & $24 \mathrm{~h}$ & 4749 & 150 & 40 & 29 & 32 & 251 & $5.0^{\mathrm{b}}$ \\
\hline & $48 \mathrm{~h}$ & 4955 & 42 & 03 & 00 & 00 & 47 & $0.9^{\mathrm{b}}$ \\
\hline \multirow{3}{*}{ B } & $\mathrm{CO}$ & 4363 & 198 & 200 & 186 & 53 & 637 & $12.7^{\mathrm{a}}$ \\
\hline & $24 \mathrm{~h}$ & 4859 & 49 & 29 & 32 & 31 & 141 & $2.8^{\mathrm{b}}$ \\
\hline & $48 \mathrm{~h}$ & 4967 & 29 & 04 & 00 & 00 & 33 & $0.7^{\mathrm{c}}$ \\
\hline \multirow{3}{*}{$\mathrm{C}$} & $\mathrm{CO}$ & 3702 & 1004 & 135 & 105 & 54 & 1298 & $26.0^{\mathrm{a}}$ \\
\hline & $24 \mathrm{~h}$ & 4492 & 304 & 91 & 94 & 19 & 508 & $10.2^{\mathrm{b}}$ \\
\hline & $48 \mathrm{~h}$ & 4819 & 152 & 29 & 00 & 00 & 181 & $3.6^{\mathrm{c}}$ \\
\hline \multirow{3}{*}{$\mathrm{D}$} & $\mathrm{CO}$ & 3901 & 841 & 109 & 78 & 71 & 1099 & $22.0^{\mathrm{a}}$ \\
\hline & $24 \mathrm{~h}$ & 4655 & 199 & 74 & 31 & 41 & 345 & $6.9^{\mathrm{b}}$ \\
\hline & $48 \mathrm{~h}$ & 4976 & 24 & 00 & 00 & 00 & 24 & $0.5^{c}$ \\
\hline \multirow{3}{*}{$\mathrm{E}$} & $\mathrm{CO}$ & 4282 & 289 & 243 & 108 & 78 & 718 & $14.4^{\mathrm{a}}$ \\
\hline & $24 \mathrm{~h}$ & 4850 & 44 & 39 & 54 & 13 & 150 & $3.0^{\mathrm{b}}$ \\
\hline & $48 \mathrm{~h}$ & 4979 & 21 & 00 & 00 & 00 & 21 & $0.4^{\mathrm{c}}$ \\
\hline \multirow{3}{*}{$\mathrm{F}$} & $\mathrm{CO}$ & 3984 & 655 & 180 & 90 & 91 & 1014 & $20.3^{\mathrm{a}}$ \\
\hline & $24 \mathrm{~h}$ & 4816 & 81 & 41 & 53 & 09 & 184 & $3.7^{\mathrm{b}}$ \\
\hline & $48 \mathrm{~h}$ & 4973 & 27 & 00 & 00 & 00 & 27 & $0.5^{\mathrm{c}}$ \\
\hline
\end{tabular}

ET - Exposure time; CO - Control; NIU - Number of cells in interphase and undifferentiated cells; P - Prophase; M - Metaphase; A - Anaphase; T - Telophase; MI - Mitotic Index; NDC - number of dividing cells. MI values followed by different letters in the same evaluated milk sample are significantly different by $\chi^{2}$ test at $5 \%$.

Table 2. Number of cellular alterations in root meristem of Allium cepa exposed for 24 and 48 hours to samples of whole long life milk of six food companies - referred to as A, B, C, D, E and F.

\begin{tabular}{|c|c|c|c|c|c|c|}
\hline Company & ET & $\begin{array}{l}\text { Colchicine } \\
\text { metaphase }\end{array}$ & $\begin{array}{c}\text { Anaphase/ } \\
\text { Telophase bridge }\end{array}$ & $\begin{array}{c}\text { Multipolar } \\
\text { anaphase }\end{array}$ & Micronucleus & NCA \\
\hline \multirow{3}{*}{ A } & $\mathrm{CO}$ & 00 & 00 & 00 & 01 & $01^{\mathrm{a}}$ \\
\hline & $24 \mathrm{~h}$ & 13 & 09 & 11 & 29 & $62^{\mathrm{b}}$ \\
\hline & $48 \mathrm{~h}$ & 00 & 00 & 00 & 01 & $01^{\mathrm{a}}$ \\
\hline \multirow{3}{*}{ B } & $\mathrm{CO}$ & 00 & 01 & 00 & 00 & $01^{\mathrm{a}}$ \\
\hline & $24 \mathrm{~h}$ & 08 & 09 & 14 & 13 & $44^{\mathrm{b}}$ \\
\hline & $48 \mathrm{~h}$ & 00 & 00 & 02 & 00 & $02^{\mathrm{a}}$ \\
\hline \multirow{3}{*}{$\mathrm{C}$} & $\mathrm{CO}$ & 00 & 01 & 00 & 00 & $01^{\mathrm{a}}$ \\
\hline & $24 \mathrm{~h}$ & 13 & 09 & 19 & 10 & $51^{\mathrm{b}}$ \\
\hline & $48 \mathrm{~h}$ & 00 & 00 & 00 & 03 & $03^{\mathrm{a}}$ \\
\hline \multirow{3}{*}{$\mathrm{D}$} & $\mathrm{CO}$ & 01 & 00 & 00 & 00 & $01^{\mathrm{a}}$ \\
\hline & $24 \mathrm{~h}$ & 04 & 11 & 11 & 13 & $39^{\mathrm{b}}$ \\
\hline & $48 \mathrm{~h}$ & 00 & 00 & 00 & 01 & $01^{\mathrm{a}}$ \\
\hline \multirow{3}{*}{$\mathrm{E}$} & $\mathrm{CO}$ & 01 & 00 & 00 & 00 & $01^{\mathrm{a}}$ \\
\hline & $24 \mathrm{~h}$ & 08 & 09 & 00 & 16 & $33^{\mathrm{b}}$ \\
\hline & $48 \mathrm{~h}$ & 00 & 00 & 02 & 00 & $02^{\mathrm{a}}$ \\
\hline \multirow{3}{*}{$\mathrm{F}$} & $\mathrm{CO}$ & 01 & 00 & 00 & 00 & $01^{\mathrm{a}}$ \\
\hline & $24 \mathrm{~h}$ & 13 & 07 & 10 & 09 & $39^{\mathrm{b}}$ \\
\hline & $48 \mathrm{~h}$ & 00 & 00 & 00 & 01 & $01^{\mathrm{a}}$ \\
\hline
\end{tabular}

CO - Control; ET - Exposure time; NCA - number of cellular alterations. Values followed by different letters in the evaluated milk sample are significantly different by $\chi^{2}$ test at $5 \%$. 
nuclear division, causing the drift of whole chromosomes at the end of cell division. In turn, Leme \& Marin-Morales (2008) point out that the multipolar anaphases are also due to spindle malfunctioning, caused by genotoxic agents, which triggers an irregular distribution of chromosomes during separation of chromatids. Furthermore, ultra-pasteurized milk also induced, by virtue of the aforementioned mitotic spindle alterations, a significant frequency of micronuclei (Table 2). Fernandes et al. (2007) reported that such alterations, characterized by loss of chromatin, are formed during telophase when the nuclear envelope is reconstituted in the daughter cells.

According to Leme \& Marin-Morales (2008), the significant presence of mitotic spindle alterations, as observed here by the action of long life milk, represents an important parameter of genotoxicity and mutagenicity of compounds or substances of interest. Thus, the data obtained with root meristem cells of $A$. серa show that the dairy products evaluated have significant potential to cause toxicity at the cellular level. This result indicates that these foods must be soon assessed in bioassays, physiologically more complex, as in animals, since, according to Queiroz et al. (2013), cellular changes, when expressively present, as evidenced in this study, when observed at a significant frequency in animal tissue, have great potential to promote tumors, once there is a positive correlation between the increased frequency of micronuclei and development of cancer in mammals.

As previously mentioned, in the literature, we have not found studies evaluating the cytotoxic, genotoxic and mutagenic potential of long life milk, as well as the microingredients added to the composition. However, it is important to mention that there is great concern on the part of health professionals and food surveillance agencies as to the addition of chemical compounds not allowed by law by the relevant regulatory bodies (Mareze et al., 2015; Rocha et al., 2015). These substances are added in an attempt to maintain specific organoleptic properties, to increase the overall yield and therefore the profit made on the sale of these foodstuffs. Among the added compounds, stand out preservatives and alkylating agents (Abrantes et al., 2014). According to information available in the literature, the most commonly used preservatives are formaldehyde and/or hydrogen peroxide, as they help to eliminate much of the microbial flora of the milk, thus extending the shelf life of these foods. Meanwhile, the major chemical compounds used as alkylating agents include caustic soda and/or bicarbonate, for assist in maintaining the homogeneity and no oxidation of the milk.

Such chemicals used in milk adulteration have been widely studied for their toxic potential and showed significant toxicity at the cellular level. Nevertheless, it is very important to emphasize that brands and even food companies were not informed in studies that check fraud made in long life milk, which does not allow to suggest that the results obtained in this study occurred as a result of adulteration.

\section{Conclusion}

All the analyzed milk samples caused, significantly, reduction in cell division and mitotic spindle changes, proving to be cytotoxic, genotoxic and mutagenic.
The results obtained on the cytotoxic, mutagenic and genotoxic at the cellular level of long life milk are of great importance because, so far, there are no published studies on toxicity involving such foods.

\section{References}

Abrantes, M. R., Silva, C. C., \& Silva, J. B. A. (2014). Fraude em leite: Métodos de detecção e implicações para o consumidor. Revista do Instituto Adolfo Lutz, 73(3), 244-251. http://dx.doi.org/10.18241/007398552014731611.

Aguiar, A. C. R. D., Rocha, V. R. Jr, Caldeira, L. A., Almeida, S. H. C. D. Fo, Ruas, J. R. M., Souza, V. M. D., \& Pires, D. A. D. A. (2015). Composição do leite de vacas alimentadas com diferentes fontes de compostos nitrogenados. Revista Brasileira de Saúde e Produção Animal, 16(3), 592-605.

Aissa, A. F., Bianchi, M. L. P., Ribeiro, J. C., Hernandes, L. C., Faria, A. F., Mercadante, A. Z., \& Antunes, L. M. G. (2012). Comparative study of $\beta$-carotene and microencapsulated $\beta$-carotene: evaluation of their genotoxic and antigenotoxic effects. Food and Chemical Toxicology, 50(5), 1418-1424. PMid:22386811. http://dx.doi. org/10.1016/j.fct.2012.02.030.

Bezerra, M. D. S., Malaquias, G. D. S., Sousa, J. M. C., \& Peron, A. P. (2016). Cytotoxic and genotoxic potential of powdered juices. Food Science and Technology (Campinas.), 36(1), 49-55. http://dx.doi. org/10.1590/1678-457X.0006.

Bianchi, J., Mantovani, M. S., \& Marin-Morales, M. A. (2015). Analysis of the genotoxic potential of low concentrations of Malathion on the Allium cepa cells and rat hepatoma tissue culture. Journal of Environmental Sciences (China), 36, 102-111. PMid:26456612. http:// dx.doi.org/10.1016/j.jes.2015.03.034.

Brasil. Agência de Vigilância Sanitária - ANVISA. (1995). Regulamentos técnicos de identidade e qualidade de produtos lácteos, Portaria ${ }^{\circ}$ 146, de 7 de março de 1995. Diário Oficial [da] República Federativa do Brasil.

Brasil. Agência Nacional de Vigilância Sanitária - ANVISA. (2007). Resolução da diretoria colegiada RDC nº 5, de 15 de Janeiro de 2007. Diário Oficial [da] República Federativa do Brasil.

Campos-Ventura, B., Marin-Morales, M. A., \& Desk S. (2016). Micronuclei and chromosome aberrations derived from the action of Atrazine herbicide in Allium cepa meristematic cells. SDRP Journal of Earth Sciences \& Environmental Studies, 1(1).

Caritá, R., \& Marin-Morales, M. A. (2008). Induction of chromosome aberrations in the Allium cepa test system caused by the exposure of seeds to industrial effluents contaminated with azo dyes. Chemosphere, 72(5), 722-725. PMid:18495201. http://dx.doi.org/10.1016/j. chemosphere.2008.03.056.

Domareski, J. L., Bandiera, N. S., Sato, R. T., \& Casale, A. A. L. (2010). Avaliação físico-química e microbiológica do leite UHT comercializado em três países do Mercosul (Brasil, Argentina e Paraguai). Archivos Latinoamericanos de Nutricion, 60(3), 261-269. PMid:21614823.

Fernandes, T. C. C., Mazzeo, D. E. C., \& Marin-Morales, M. A. (2007). Mechanism of micronuclei formation in polyploidizated cells of A. cepa exposed to trifluralin herbicide. Pesticide Biochemistry and Physiology, 88(3), 252-259. http://dx.doi.org/10.1016/j.pestbp.2006.12.003.

Gomes, K. M. S., Oliveira, M. V. G. A., Carvalho, F. R. S., Menezes, C. C., \& Peron, A. P. (2013). Citotoxicity of food dyes sunset yellow (E-110), bordeax red (E-123), and tatrazine yellow (E-102) on Allium cepa L. root meristematic cells. Food Science and Technology (Campinas.), 33(1), 218-223. http://dx.doi.org/10.1590/S0101-20612013005000012. 
Guerra, M., \& Souza, M. J. (2002). Como observar os cromossomos: um guia de técnicas em citogenética vegetal, animal e humana. Ribeirão Preto: FUNPEC.

Herrero, O., Martín, J. P., Freire, P. F., López, L. C., Peropadre, A., \& Hazen, M. J. (2012). Toxicological evaluation of three contaminant of emerging concern by use of Allium cepa test. Mutation Research/ Genetic Toxicology and Environmental Mutagenesis, 743(1), 20-24. PMid:22249112. http://dx.doi.org/10.1016/j.mrgentox.2011.12.028.

Lacerda, L. P., Malaquias, G., \& Peron, A. P. (2014). Antiproliferative action of aqueous extracts of Hymenaea stigonocarpa Mart. (Fabaceae) on the cell cycle of Allium cepa L. Anais da Academia Brasileira de Ciencias, 89(3), 1147-1150. PMid:25029361. http:// dx.doi.org/10.1590/0001-3765201420130163.

Leme, D. M., \& Marin-Morales, M. A. (2008). Chromosome aberration and micronucleis frequencies in A. cepa cells exposed to petroleum polluted water: a case study. Mutation Research, 650(1), 80-86. PMid:18068420. http://dx.doi.org/10.1016/j.mrgentox.2007.10.006.

Lima, F. M., Brunini, M. A., Maciel, V. A. Jr, Morandin, C. S., \& Ribeiro, C. T. (2009). Qualidade de leite UHT integral e desnatado, comercializado na cidade de São Joaquim da Barra, SP. Nucleus Animalium, 1(1), 1-9. http://dx.doi.org/10.3738/1982.2278.187.

Mareze, J., Marioto, L. R. M., Gonzaga, N., Daniel, G. C., Tamanini, R., \& Beloti, V. (2015). Detecção de adulterações do leite pasteurizado por meio de provas oficiais. Semina: Ciências Biológicas e da Saúde, 36, 283-290. http://dx.doi.org/10.3738/1982.2278.187.

Marques, G. S., Silva, S. I. O., Sousa, J. M. C., Ferreira, P. M. P., \& Peron, A. P. (2015). Cytotoxicity and mutagenic potential of liquid synthetic food flavoring evaluated individually and in association. Food Science and Technology (Campinas.), 35(1), 183-188. http:// dx.doi.org/10.1590/1678-457X.6596.

Moura, A. G., Santana, G. M., Ferreira, P. M. P., Sousa, J. M. C., \& Peron, A. P. (2016). Cytotoxicity of Cheese and Cheddar Cheese food flavorings on Allim cepa L root meristems. Brazilian Journal of Biology = Revista Brasileira de Biologia, 76(2), 439-443. PMid:26959949. http://dx.doi.org/10.1590/1519-6984.20514.

Neves, E. S., Ferreira, P. M. P., Lima, L. H., \& Peron, A. P. (2014). Action of aqueous extracts of Phyllanthus niruri L. (Euphorbiaceae) leaves on meristematic root cells of Allium cepa L. Anais da Academia Brasileira de Ciencias, 86(3), 1131-1137. PMid:25098312. http:// dx.doi.org/10.1590/0001-3765201420130170.

Nunes, R. D. M., Sales, I. M. S., Silva, S. I. O., Sousa, J. M. C., \& Peron, A. P. (2016). Antiproliferative and genotoxic effects of nature identical and artificial synthetic food additives of aroma and flavor. Brazilian Journal of Biology $=$ Revista Brasileira de Biologia. In press. PMid:27463833. http://dx.doi.org/10.1590/1519-6984.12115.
Oliveira, M. V. A., Alves, D. D. L., Lima, L. H. G. M., Castro, J. M. C., \& Peron, A. P. (2013). Cytotoxicity of erytrosine (E-127), brilliant blue (E-133) and red 40 (E-129) food dyes plant test system. Acta Scientiarum. Biological Science, 5(4), 557-562. http://dx.doi. org/10.4025/actascibiolsci.v35i4.18419.

Pflanzer, S. B., Cruz, A. G. D., Hatanaka, C. L., Mamede, P. L., Cadena, R., Faria, J. A. F., \& Silva, M. A. A. P. D. (2010). Perfil sensorial e aceitação de bebida láctea achocolatada. Food Science and Technology (Campinas.), 30(2), 391-398. http://dx.doi.org/10.1590/S010120612010000200016.

Queiroz, F. M. D., Matias, K. W. D. O., Cunha, M. M. F. D., \& Schwarz, A. (2013). Evaluation of (anti) genotoxic activities of Phyllanthus niruri L. in rat bone marrow using the micronucleus test. Brazilian Journal of Pharmaceutical Sciences, 49(1), 135-148. http://dx.doi. org/10.1590/S1984-82502013000100015.

Rocha, P. C. A., Cunha, L. M. M., Machado, A. V., \& Oliveira, R. C. (2015). Análises microbiológicas do leite e tipos de adulterações. Revista Brasileira de Agrotecnologia, 5(1), 1-6.

Sales, I. M. S., \& Peron, A. P. (2016). Toxicity of synthetic flavorings, nature identical and artificial, to hematopoietic tissue cells of rodents. Brazilian Journal of Biology = Revista Brasileira de Biologia. In press.

Santana, G. M., Deus, M. S. M., Sousa, J. M. C., Fernandes, P. M. P., \& Peron, H. B. (2016). Antimitotic and antimutagenic action of the Hymenaea stigonocarpa bark on dividing cells. Brazilian Journal of Biology = Revista Brasileira de Biologia, 76(2), 520-525. PMid:27058600. http://dx.doi.org/10.1590/1519-6984.23014.

Souza, L. V., Souza, C. B., Batista, C. S., Martins, M. L., Pinto, C. M. F., \& Oliveira, C. L. P. (2014). Avaliação da qualidade microbiológica e físico-química de leite UHT integral processado em indústrias do Estado de Minas Gerais, Brasil. Revista Brasileira de Agropecuária Sustentável, 4(2), 5-15.

Tabrez, S., Sahkil, S., Urooj, M., Damanhori, G. A., Abuzenadah, A. M., \& Ahmad, D. (2011). Genotoxicity testing and biomarker studies on surface water: an over view of the techniques and their efficacies. Journal of Environmental Science and Health. Part C, 29(3), 250-275. http://dx.doi.org/10.1080/10590501.2011.601849.

Taffarel, L. E., Costa, P. B., Oliveira, N. T. E., Braga, G. C., \& Zonin, W. J. (2013). Total bacterial count of milk in different systems of milking and cooling. Arquivos do Instituto Biologico, 80(1), 7-11. http://dx.doi.org/10.1590/S1808-16572013000100002.

Türkoğlu, Ş. (2007). Genotoxicity of five food preservatives tested on root tips of Allium cepa L. Mutation Research, 626(1-2), 4-14. PMid:17005441. http://dx.doi.org/10.1016/j.mrgentox.2006.07.006. 